\title{
COMPARATIVE ANALYSIS OF INDONESIA CAPITAL MARKET REACTION BEFORE AND AFTER ANNOUNCEMENT OF PRESIDENTIAL ELECTIONS UNITED STATES 2016 DONALD TRUMP (Event Studies On Shares Member Index LQ-45)
}

\begin{tabular}{|c|c|}
\hline \multicolumn{2}{|c|}{ STIE Sutaatmadja (STIESA) Subang } \\
\hline INFO ARTIKEL & ABSTRAK/ABSTRACK \\
\hline $\begin{array}{l}\text { Histori Artikel : } \\
\text { Tgl Masuk : } 25 \text { Okt. } 2017 \\
\text { Tgl Diterima : } 7 \text { Feb. } 2018 \\
\text { Tersedia Online: } 5 \text { Maret } 2018 \\
\text { Keywords: } \\
\text { United States Presidential } \\
\text { Election 2016, Event Study, } \\
\text { Abnormal Return, Stock Trading } \\
\text { Volume Activity, Stock Trading } \\
\text { Frequency Activity. }\end{array}$ & $\begin{array}{l}\text { This study aims to determine the empirical evidence of } \\
\text { differences before and after the announcement of the results } \\
\text { of the election of President of the United States } 2016 \text { Donald } \\
\text { Trump against the average abnormal return, trading volume } \\
\text { trading activities, and frequency trading activities of shares } \\
\text { in the capital market in Indonesia. } \\
\text { This study is an event study with a 15-day window event that } \\
\text { begins on October } 312016 \text { (t-7) to November } 18,2016 \text { (t+7) } \\
\text { and the date of the announcement of the } 2016 \text { Presidential } \\
\text { Election of the United States of America which falls on } \\
\text { November } 9,2016 \text { as (t0). The sample used in this research is } \\
24 \text { stock members of LQ-45 index chosen by purposive } \\
\text { sampling method. The data used in this study is secondary } \\
\text { data sourced from the website of Indonesia Stock Exchange } \\
\text { (http://www.idx.co.id/). Expected return in this study using } \\
\text { market model. Then the data is analyzed using Microsoft } \\
\text { Excel } 2010 \text { and SPSS } 22 \text { applications. } \\
\text { The result of the research shows that based on the result of } \\
\text { paired-samples t-test it can be concluded that statistically } \\
\text { the average difference of abnormal return variable before } \\
\text { and after announcement of election result of President of } \\
\text { United States } 2016 \text { Donald Trump, then based on result of } \\
\text { wilcoxon signed rank test can be concluded that statistically } \\
\text { the average difference of trading volume activity volume } \\
\text { variables, and the frequency of trading activity of stock } \\
\text { before and after the announcement of the result of the } \\
\text { election of President of the United States } 2016 \text { Donald } \\
\text { Trump. }\end{array}$ \\
\hline
\end{tabular}

\section{LATAR BELAKANG}

Keberadaan pasar modal (capital market) merupakan suatu realitas dan menjadi fenomena terkini ditengahtengah kehidupan di abad modern ini, pasar modal memiliki peranan yang penting dan menjadi indikator kemajuan bagi perekonomian suatu negara. Bahkan hampir di seluruh negara manapun termasuk di Indonesia. Aktivitas pasar modal merupakan 
instrumen yang penting dan berperan besar dalam memajukan perekonomian Indonesia dimasa yang akan datang karena, berdasarkan Undang-Undang Nomor 8 Tahun 1995 tentang Pasar Modal, pasar modal Indonesia memiliki posisi strategis sebagai salah satu sumber pembiayaan bagi dunia usaha dan wahana investasi bagi masyarakat (Rivaldi, 2016). Perkembangan aktivitas pasar modal yang pesat membawa perubahan besar pada tuntutan kualitas informasi. Keterbukaan informasi merupakan suatu kata kunci dalam pasar modal, sehingga informasi terkait dengan proses penyampaian dan penerimaan bagi perusahaan dan masyarakat dapat berlangsung (Yusuf, et al, 2009).

Pasar modal memiliki peran penting bagi perekonomian suatu negara karena pasar modal menjalankan dua fungsi, yaitu pertama sebagai sarana bagi pendanaan usaha atau sebagai sarana bagi perusahaan untuk mendapatkan dana dari masyarakat pemodal (investor). Dana yang diperoleh dari pasar modal dapat digunakan untuk pengembangan usaha, ekspansi, penambahan modal kerja dan lain-lain. Kedua pasar modal menjadi sarana bagi masyarakat untuk berinvestasi pada instrumen keuangan seperti saham, obligasi, reksadana, dan lain-lain. Dengan demikian, masyarakat dapat menempatkan dana yang dimilikinya sesuai dengan karakteristik keuntungan dan risiko masing-masing instrumen (http://www.idx.co.id). Selain memiliki fungsi sebagai sarana pendanaan dan investasi pasar modal juga bertujuan untuk menghimpun kesempatan pada masyarakat untuk bersama-sama meningkatkan pertumbuhan ekonomi negara dengan menyalurkan dananya di pasar modal.

Dalam perkembangannya, instrumen keuangan di pasar ekuitas terutama saham di pasar modal selalu mengalami fluktuasi yang dapat dipengaruhi oleh faktor ekonomi dan non ekonomi (Kristiana dan Suratna, 2005:122). Faktor ekonomi terdiri dari lingkungan ekonomi mikro dan makro. Lingkungan ekonomi mikro seperti pengumuman laporan keuangan, pengumuman deviden, dan pemecah saham (stock split) serta lingkungan makro seperti perubahan suku bunga, kurs valuta asing, dan inflasi. Faktor non ekonomi walaupun tidak terkait secara langsung dengan dinamika yang terjadi di pasar modal, namun pengaruh lingkungan non ekonomi tidak dapat dipisahkan dari pasar modal (Baiquni, 2015). Yuwono (2013) dalam Asri dan Arief (1998:137) mengemukakan bahwa faktor non ekonomi seperti isu-isu mengenai kepedulian terhadap lingkungan hidup, hak asasi manusia, peristiwa-peristiwa politik dan kenegaraan serta kerusuhan-kerusuhan yang menyebabkan ketidakpastian politik dan keamanan, sering menjadi faktor utama pemicu fluktuasi harga saham di bursa efek secara seluruh dunia.

Bursa efek atau bursa saham adalah suatu sistem yang terorganisasi yang mempertemukan penjual dan pembeli efek yang dilakukan baik secara langsung maupun melalui wakil-wakilnya (Tarigan, et al, 2016). Bursa efek disuatu negara umunya sensitif terhadap berbagai peristiwa disekitarnya baik dalam negeri maupun luar negeri. Kondisi politik seperti pergantian Presiden merupakan salah satu faktor yang memungkinkan mempengaruhi pasar modal termasuk peristiwa politik yang terjadi di negaranegara dengan perekonomian yang cukup kuat seperti Amerika Serikat. Amerika Serikat merupakan negara adidaya dimana dalam setiap kebijakannya baik dalam bidang perekonomian, politik, maupun dalam bidang yang lain 
akan dapat berpengaruh terhadap keadaan suatu negara yang bergantung atau bekerjasama dengannya. Memasuki akhir tahun 2016, Negara Amerika Serikat telah mengumumkan terpilihnya Donald Trump sebagai Presiden Amerika Serikat ke-45 dari partai Republik yang berhasil mengalahkan lawannya Hillary Clinton dari partai Demokrat. Peristiwa terpilihnya Donald Trump menimbulkan kekhawatiran bagi negara-negara lain dengan kebijakan-kebijakannya. Kebijakan Donald Trump tersebut antara lain:

1. Pemotongan pajak secara besarbesaran, dimana pajak yang ada di Amerika Serikat mencapai 35\%.

2. Lapangan Pekerjaan yang terutama penyerapan tersebut difokuskan di sektor manufaktur.

3. Setiap perdagangan bebas yang berada di Amerika harus bersikap proteksionisme, artinya setiap transaksi perdagangan harus melindungi produk dalam negeri Amerika Serikat dari berbagai produk luar negeri.

4. Menentang kesepakatan TPP (Trans Pacific Partnership) antara Amerika Serikat dengan negara yang berada dikawasan pasifik dan akan menetapkan standar perdagangan umum

(http://www.kompasiana.com).

Namun, persoalannya banyak pula ekonom yang setuju dengan kebijakan ekonomi Donald Trump, dengan kebijakan yang inward looking tanpa terlalu memedulikan kepentingan ekonomi global, kebijakan Donald Trump justru dinilai bisa membangkitkan kembali perekonomian Amerika Serikat. Sebaliknya dengan kemenangan Donald Trump dari partai Republik, membuat perekonomian terutama bursa saham dinilai akan membawa pengaruh "Trump Effect" yang cukup signifikan bagi perekonomian di berbagai negaranegara di Asia termasuk bursa saham pada indeks LQ45 di Indonesia. Indeks LQ45 merupakan kumpulan saham yang dipilih berdasarkan pertimbangan faktor likuiditas tinggi serta saham unggulan yang diseleksi melalui beberapa kriteria pemilihan, tak luput dari pengaruh kondisi politik menjelang pengumuman hasil pemilihan Presiden Amerika Serikat 2016 Donald Trump.

Berdasarkan fenomena politik dan research gap yang masih belum konslusif tersebut, maka penelitian ini ditujukan untuk menemukan bukti empiris pada kondisi perekonomian Indonesia apakah memiliki pengaruh terhadap perekonomian Indonesia khususnya pada bursa saham indeks LQ-45 di dalam pasar modal. Studi peristiwa (event study) pada penelitian ini dilakukan dengan mengamati pergerakan harga saham, aktivitas volume perdagangan saham, dan aktivitas frekuensi perdagangan saham di pasar modal. Jika pengumuman hasil pemilihan Presiden Amerika Serikat Donald Trump mengandung informasi, maka diharapkan pasar akan bereaksi yang ditunjukkan dengan adanya perubahan harga saham, aktivitas volume perdagangan saham, dan aktivitas frekuensi perdagangan saham. Perubahan harga saham akan mengakibatkan perbedaan rata-rata abnormal return sebelum dan sesudah pengumuman hasil pemilihan Presiden Amerika Serikat 2016 Donald Trump, sedangkan perubahan aktivitas volume perdagangan saham akan mengakibatkan perbedaan ratarata trading volume activity sebelum dan sesudah pengumuman hasil pemilihan Presiden Amerika Serikat 2016 Donald Trump, dan perubahan aktivitas frekuen- 
si perdagangan saham akan mengakibatkan perbedaan rata-rata jumlah terjadinya transaksi perdagangan sebelum dan sesudah pengumuman hasil pemilihan Presiden Amerika Serikat 2016 Donald Trump.

Berdasarkan latar belakang dan fenomena tersebut maka penulis tertarik untuk melakukan penelitian dengan judul "ANALISIS PERBANDINGAN REAKSI PASAR MODAL INDONESIA SEBELUM DAN SESUDAH PENGUMUMAN HASIL PEMILIHAN PRESIDEN AMERIKA SERIKAT 2016 DONALD TRUMP (STUDI PERISTIWA PADA SAHAM ANGGOTA INDEKS LQ45)".

\section{TINJAUAN PUSTAKA}

\section{Teori Sinyal (Signalling Theory)}

Teori sinyal (signaling theory) dikembangkang oleh Ross (1977). Dewi, et al, (2013) dalam Mutlasih (2009) mengungkapkan bahwa :

Teori sinyal mengasumsikan bahwa manajemen mempunyai informasi yang akurat tentang nilai perusahaan yang tidak diketahui oleh investor luar sehingga apabila semua informasiinformasi yang dapat mempengaruhi perusahaan tidak disampaikan ke publik oleh manajemen, maka saat manajemen menyampaikan informasi itu ke publik, informasi tersebut akan dianggap sebagai suatu sinyal dan akan membuat pasar bereaksi.

Apapun informasi yang terjadi dari kondisi saham suatu perusahaan adalah selalu memberi efek bagi keputusan investor sebagai pihak yang menangkap sinyal tersebut. Informasi yang lengkap, relevan, akurat dan tepat waktu sangat diperlukan investor di pasar modal sebagai alat analisis untuk mengambil keputusan investasi. Informasi yang dipublikasikan sebagai suatu pengumuman akan memberikan sinyal bagi investor dalam pengambilan keputusan investasi.

\section{Teori Pasar Modal Efisien}

Menurut satu interpretasi dari pendekatan prediktif, pengamatan atas reaksi pasar modal dapat digunakan sebagai satu panduan dalam mengevaluasi dan melakukan pilihan di antara beberapa ukuran akuntansi. Sebagai contoh, Belkaoui (2007:138) dalam Gonedes (1972) berpendapat bahwa :

Pengamatan atas reaksi pasar terhadap penerimaan output akuntansi hendaknya mengarahkan evaluasi dari kandungan informasi aktual angka-angka akuntansi yang diproduksi melalui seperangkat prosedur tertentu dan kandungan informasi angka-angka akuntansi yang diproduksi melalui prosedur-prosedur alternatif.

Belkaoui (2007:138) dalam Beaver dan Dukes (1972) mendukung pendekatan prediktif ketika mereka menyatakan bahwa :

Metode yang menghasilkan angkaangka laba yang memiliki keterkaitan tertinggi dengan harga-harga surat berharga adalah metode yang paling konsisten dengan informasi yang menghasilkan suatu penentuan harga surat berharga secara efisien. Metode itu adalah metode yang seharusnya dilaporkan.

\section{Konsep Pasar Modal Efisien}

Tandelilin (2010:219) menyatakan bahwa : "Konsep pasar yang efisien lebih 
ditekankan pada aspek informasi, artinya pasar yang efisien adalah pasar di mana harga semua sekuritas yang diperdagangkan telah mencerminkan semua informasi yang tersedia." Dalam hal ini, informasi yang tersedia bisa meliputi semua informasi yang tersedia baik informasi di masa lalu (misalkan laba perusahaan tahun lalu), maupun informasi saat ini (misalkan rencana kenaikan dividen tahun ini), serta informasi yang bersifat sebagai pendapat/opini rasional yang beredar di pasar yang bisa mempengaruhi perubahan harga (misal, jika banyak investor di pasar berpendapat bahwa harga saham akan naik, maka akan informasi tersebut nantinya akan tercermin pada perubahan harga saham yang cenderung naik).

\section{Return}

Return merupakan hasil yang diperoleh dari investasi. Return dapat berupa return realisasian yang sudah terjadi atau return ekspektasian yang belum terjadi tetapi yang diharapkan akan terjadi dimasa mendatang (Jogiyanto, 2016). Sumber-sumber return investasi terdiri dari dua komponen utama, yaitu yield dan capital gain (loss). Yield merupakan komponen utama return yang mencerminkan aliran kas atau pendapatan yang diperoleh secara periodik dari suatu investasi. Misalnya, berinvestasi pada sebuah obligasi maka besarnya yield ditunjukkan dari bunga obligasi yang dibayarkan. Demikian pula halnya jika kita membeli saham, yield ditunjukkan oleh besarnya dividen yang kita peroleh. Sedangkan, capital gain (loss) sebagai komponen kedua dari return merupakan kenaikan (penurunan) harga suatu surat berharga (bisa saham maupun surat hutang jangka panjang). Dalam kata lain, capital gain (loss) bisa juga diartikan sebuah perubahan harga sekuritas (Tandelilin, 2010).

\section{Return Realisasi}

Return realisasian (realized return) merupakan return yang terjadi. Return realisasian dihitung menggunakan data historis. Return realisasian penting karena digunakan sebagai salah satu pengukur kinerja dari perusahaan karena, return realisasian bagi perusahaan dapat digunakan untuk mengukur pengembalian modal untuk investor dan keuntungan untuk keberlangsungan perusahaan sedangkan bagi investor merupakan hasil perolehan return sesungguhnya yang didapat oleh investor selama berinvestasi. Return ini juga digunakan sebagai dasar penentuan return ekspektasi dan risiko di masa yang akan mendatang.

\section{Return Ekspektasian (Market Model) dan Abnormal Return}

Return ekspektasian (expected return) adalah return yang diharapkan akan diperoleh oleh investor dimasa mendatang. Berbeda dengan return realisasian yang sifatnya sudah terjadi, return ekspektasian sifatnya belum terjadi. Return ekspektasi merupakan return yang digunakan untuk pengambilan keputusan investasi. Return ini penting dibandingkan dengan return historis, karena return ekspektasi merupakan return yang diharapkan dari investasi yang dilakukan (Lestari, 2014).

Model sesuaian pasar (market adjusted model) menganggap bahwa penduga yang terbaik untuk mengestimasi return suatu sekuritas adalah return indeks pasar pada saat tersebut. Dengan menggunakan model ini, maka tidak perlu menggunkan periode estimasi untuk membentuk 
model estimasi, karena return sekuritas yang diestimasi adalah sama dengan return indeks pasar.

Abnormal return atau excess return merupakan kelebihan dari return yang sesungguhnya terjadi terhadap return normal. Return normal merupakan return ekspektasian (return yang diharapkan oleh investor). Dengan demikian, return tak normal (abnormal return) adalah selisih antara return sesungguhnya yang terjadi dengan return ekspektasian. Selisih return akan positif jika return yang didapatkan lebih besar dari yang diharapkan. Sebaliknya, selisih return akan negatif jika return yang didapatkan lebih kecil dari return yang diharapkan. Abnormal return dapat terjadi karena adanya peristiwa tertentu, seperti corporate action dan kondisi politik yang tak menentu.

\section{Aktivitas Volume Perdagangan Saham (Trading Volume Activity)}

Darwis (2013) mendefinisikan : "volume perdagangan sebagai jumlah lembar saham yang diperdagangan pada periode tertentu." Menurut Jogiyanto (2010) aktivitas volume perdagangan saham adalah : "jumlah lembar saham yang diperdagangkan secara harian." Sehingga dapat disimpulkan bahwa aktivitas volume perdagangan saham merupakan jumlah lembar saham yang diperdagangkan dalam kurun waktu tertentu. Perkembangan harga dan aktivitas volume perdagangan saham di pasar modal merupakan suatu indikator penting untuk mempelajari tingkah laku pasar yaitu investor. Naiknya aktivitas volume perdagangan saham dapat menambah informasi yang berguna bagi investor secara kontinyu dalam periode perdagangan seperti saat aktivitas volume perdagangan saham dalam jumlah kecil yang menyebabkan harga jatuh. Semakin tinggi minat atau permintaan saham semakin mendorong kenaikan harga saham (Darwis, 2013).

\section{Aktivitas Frekuensi Perdagangan Saham}

Silviyani (2013) dalam Harsono (2003:179) menyatakan bahwa: "aktivitas frekuensi perdagangan saham adalah berapa kali transaksi jual beli terjadi pada saham yang bersangkutan pada waktu tertentu."

Taslim (2015) dalam Yahya (2008) mendefinisikan: "Frekuensi adalah berapa kali saham tersebut diperdagangkan." Sehingga dapat disimpulkan bahwa frekuensi perdagangan merupakan jumlah terjadinya transaksi perdagangan pada saham itu sendiri.

Kurniawan (2014) menyatakan bahwa : "Dalam aktivitas bursa efek ataupun pasar modal, aktivitas frekuensi perdagangan saham merupakan salah satu elemen yang menjadi salah satu bahan untuk melihat reaksi pasar terhadap sebuah informasi yang masuk pada pasar modal." Perkembangan harga saham dan aktivitas frekuensi perdagangan saham di pasar modal menjadi indikasi penting untuk mempelajari tingkah laku pasar sebagai acuan pasar modal dalam menentukan transaksi di pasar modal.

\section{Studi Peristiwa (Event Study)}

Studi peristiwa merupakan bagian dalam konsep hipotesis pasar efisien (efficient market hypothsis) yang dikemukakan oleh Fama (1991). Studi peristiwa merupakan bentuk studi untuk menguji efisiensi pasar bentuk setengah kuat (semi-strong form). Secara lebih spesifik studi peristiwa menyelidiki respons pasar terhadap kandungan 
informasi dari suatu pengumuman atau publikasi peristiwa tertentu. Kandungan informasi dapat berupa berita baik (good news) atau berita buruk (bad news) (Tandelilin, 2010:565).

Menurut Jogiyanto (2016:623) : "studi peristiwa (event study) merupakan studi yang mempelajari reaksi pasar terhadap suatu peristiwa (event) yang informasinya dipublikasikan sebagai suatu pengumuman." Event study dapat digunakan untuk menguji kandungan informasi (information content) dari suatu pengumuman dan dapat juga digunakan untuk menguji efisiensi pasar bentuk setengah kuat.

\section{Kerangka Pemikiran}

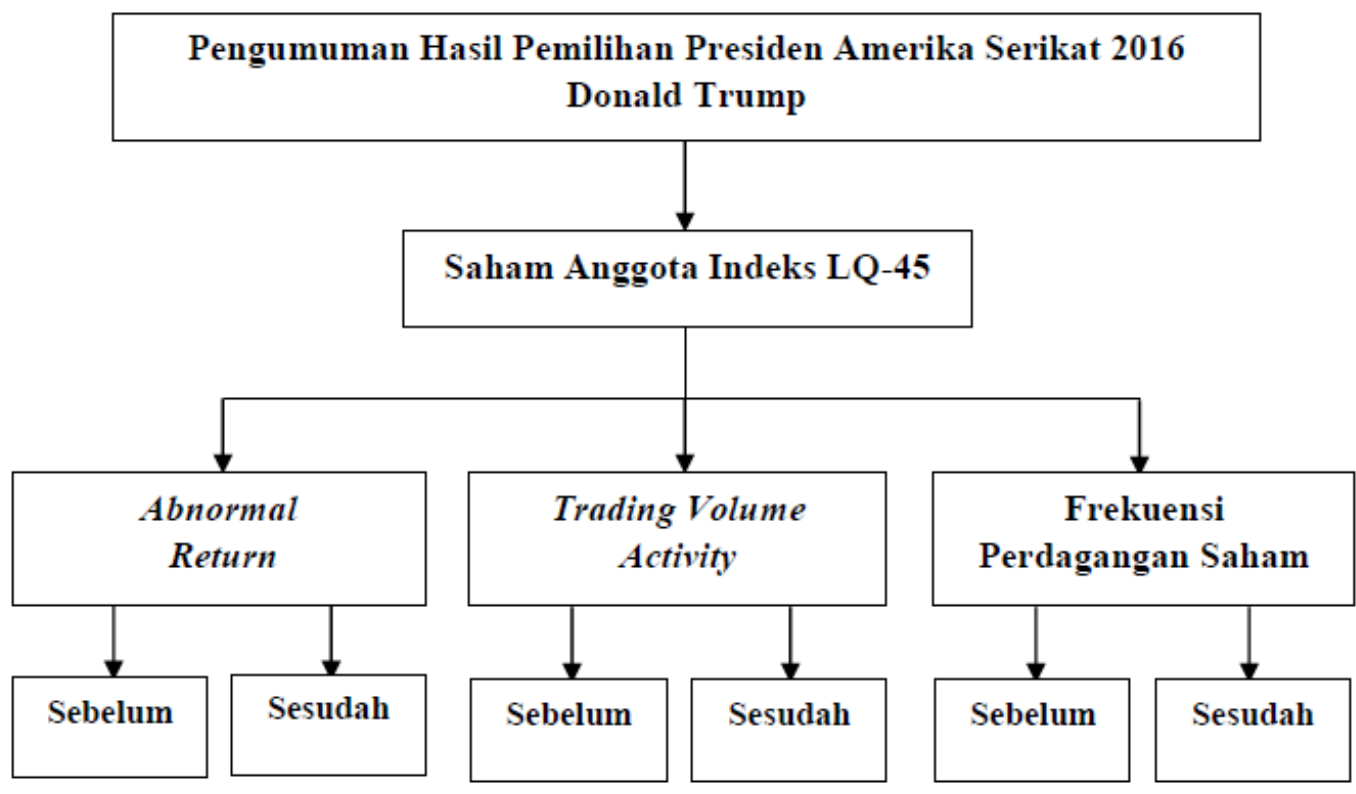

\section{Gambar 1}

Kerangka Pemikiran

Sumber : Penulis (2017)

\section{PENGEMBANGAN HIPOTESIS}

\section{Pengaruh Pengumuman Hasil Pemilihan Presiden Amerika Serikat 2016 Donald Trump Terhadap Abnormal Return}

Pengumuman hasil pemilihan Presiden Amerika Serikat 2016 Donald Trump merupakan peristiwa yang dapat mempengaruhi aktivitas pasar modal. Hal ini dikarenakan informasi yang terkandung dalam pengumuman tersebut dapat dijadikan pertimbangan oleh investor dalam mengambil keputusan investasi. Reaksi pasar modal atas pengumuman tersebut ditunjukkan dengan adanya perubahan harga saham. Perubahan harga saham akan mengakibatkan perbedaan rata-rata abnormal return yang signifikan sebelum dan sesudah pengumuman hasil pemilihan Presiden Amerika Serikat 2016 Donald Trump.

Penelitian yang dilakukan oleh Wibowo (2017) yang meneliti "Reaksi 
Investor Pasar Modal Indonesia Terhadap Paket Kebijakan Ekonomi Tahap I Jokowi-JK" menunjukkan terdapat perbedaan rata-rata abnormal return yang signifikan sebelum dan sesudah. Hasil tersebut sejalan dengan penelitian yang dilakukan oleh Utami, et al, (2017) yang meneliti "Reaksi Investor Dalam Pasar Modal Terhadap Peristiwa Menguatnya Kurs Dolar Amerika Serikat Pada Nilai Tukar Rupiah (Event Study pada Peristiwa Menguatnya Kurs Dolar AS Terhadap Nilai Tukar Rupiah Tanggal 26 Agustus 2015)", dan Wulandari, et al, (2017) yang meneliti "Reaksi Investor Dalam Pasar Modal Terhadap UndangUndang Tax Amnesty (Event Study Pada Perusahaan yang Terdaftar Dalam LQ45 di Bursa Efek Indonesia). Hasil-hasil penelitian tersebut menunjukkan terdapat perbedaan rata-rata abnormal return yang signifikan sebelum dan sesudah peristiwa.

Berdasarkan uraian di atas, maka penulis merumuskan hipotesis sebagai berikut :

H1 : Terdapat perbedaan rata-rata
abnormal return yang signifikan
sebelum dan sesudah pengu-
muman hasil pemilihan Presiden
Amerika Serikat 2016 Donald
Trump.

\section{Pengaruh Pengumuman Hasil Pemilihan Presiden Amerika Serikat 2016 Donald Trump Terhadap Aktivitas Volume Perdagangan Saham}

Reaksi pasar modal atas pengumuman hasil pemilihan Presiden Amerika Serikat 2016 Donald Trump juga dapat ditunjukkan dengan adanya perubahan aktivitas volume perdagangan saham. Apabila jumlah lembar saham berubah setelah adanya peristiwa tersebut maka akan mempengaruhi terhadap harga atau return saham. Perubahan aktivitas volume perdagangan saham akan mengakibatkan perbedaan rata-rata aktivitas volume perdagangan saham (trading volume activity) yang signifikan sebelum dan sesudah pengumuman hasil pemilihan Presiden Amerika Serikat 2016 Donald Trump.

Penelitian yang dilakukan oleh Wulandari, et al, (2017) yang meneliti "Reaksi Investor Dalam Pasar Modal Terhadap Undang-Undang Tax Amnesty (Event Study Pada Perusahaan yang Terdaftar Dalam LQ45 di Bursa Efek Indonesia)" menunjukkan terdapat perbedaan rata-rata aktivitas volume perdagangan saham yang signifikan sebelum dan sesudah peristiwa. Hasil tersebut sejalan dengan Ervina Ratna Ningsih dan Dwi Cahyaningdyah (2014) "Reaksi Pasar Modal Indonesia Terhadap Pengumuman Kenaikan Harga BBM 22 Juni 2013", Stesia Juliana Liogu dan Ivonne S. Saerang (2015) "Reaksi Pasar Modal Terhadap Pengumuman Kenaikan Harga BBM Atas Saham LQ 45 Pada Tanggal 1 November 2014". Hasil-hasil penelitian tersebut menunjukkan terdapat perbedaan rata-rata aktivitas volume perdagangan saham sebelum dan sesudah peristiwa.

Berdasarkan uraian di atas, maka penulis merumuskan hipotesis sebagai berikut:

H2 : Terdapat perbedaan rata-rata aktivitas volume perdagangan saham yang signifikan sebelum dan sesudah pengumuman hasil pemilihan Presiden Amerika Serikat 2016 Donald Trump.

\section{Pengaruh Pengumuman Hasil Pemilihan Presiden Amerika Serikat}




\section{Donald Trump Terhadap Aktivitas Frekuensi Perdagangan Saham}

Peristiwa pengumuman hasil pemilihan Presiden Amerika Serikat 2016 Donald Trump juga bisa berdampak pada aktivitas frekuensi perdagangan saham. Aktivitas frekuensi perdagangan saham merupakan jumlah terjadinya transaksi perdagangan yang bersangkutan pada waktu tertentu. Dengan melihat berapa kali atau frekuensi yang diperdagangkan, dapat dilihat bahwa saham tersebut diminati tidaknya oleh investor. Apabila informasi pemihan tersebut mempengaruhi pasar modal dapat menurunkan atau meningkatkan jumlah frekuensi transaksi perdagangan dan mempengaruhi pergerakan harga saham. Dalam aktivitas bursa efek ataupun pasar modal, aktivitas frekuensi perdagangan saham merupakan salah satu elemen yang menjadi salah satu bahan untuk melihat reaksi pasar terhadap sebuah informasi yang masuk pada pasar modal.

Berdasarkan uraian tersebut, maka penulis merumuskan hipotesis sebagai berikut :

H3 : Terdapat perbedaan rata-rata aktivitas frekuensi perdagangan saham yang signifikan sebelum dan sesudah pengumuman hasil pemilihan Presiden Amerika Serikat 2016 Donald Trump.

\section{METODE PENELITIAN}

Data yang digunakan dalam penelitian ini adalah data perdagangan saham anggota indeks LQ-45 periode 31 Oktober 2016 - 18 November 2016. Data tersebut bersumber dari Bursa Efek Indonesia (BEI). Berdasarkan klasifikasi sumber, maka jenis data yang digunakan dalam penelitian ini adalah data skunder.
Data yang digunakan dalam penelitian ini terdiri dari :

1. Harga saham. Harga saham yang digunakan adalah harga penutupan (closing price).

2. Nilai indeks LQ-45.

3. Volume perdagangan saham.

4. Frekuensi perdagangan saham.

5. Jumlah saham beredar.

Penelitian ini dilakukan selama tujuh hari bursa dengan event window dimulai pada 7 hari sebelum ( $t-7)$ sampai dengan 7 hari sesudah $(t+7)$. Dengan demikian, penelitian ini dimulai pada tanggal 31 Oktober 2016 sampai dengan 18 November 2016. Periode tersebut dipilih untuk menghindari confounding effect dari peristiwa lain yang dapat mempengaruhi harga saham, aktivitas volume perdagangan saham (trading volume activity), dan aktivitas frekuensi perdagangan saham.

Selain itu, teknik analisis data yang digunakan untuk pengujian yaitu analisis deskriftif, uji normalitas, dan uji beda. Alat statistika yang digunakan dalam penelitian ini yaitu Microsoft Excel 2010 dan program Statistical Product and Service Solutions (SPSS) 22.

Metode pengumpulan data yang dilakukan dalam penelitian ini adalah studi kepustakaan, yaitu data diperoleh dari beberapa literature yang berkaitan dengan masalah yang sedang diteliti. Penelusuran data ini dilakukan dengan cara:

1. Penelusuran secara manual untuk data dalam format kertas hasil cetakan. Data yang disajikan dalam format kertas hasil cetakan antara lain berupa jurnal, buku dan thesis yang berhubungan dengan pasar modal. 
2. Penelusuran dengan menggunakan komputer untuk data dalam format elektronik. Data yang disajikan dalam format elektronik antara lain berupa harga saham harian sebelum dan sesudah pengumuman hasil pemilihan Presiden Amerika Serikat 2016 Donald Trump yang dapat diunduh melalui website Bursa Efek Indonesia (http://www.idx.co.id), dan situs internet lainnya.

Teknik sampling adalah teknik pengambilan sampel. Dalam penelitian ini teknik pemilihan sampel yang digunakan adalah Sampling Purposive. Sampling Purposive adalah teknik penentuan sampel dengan pertimbangan tertentu (Sugiyono, 2016:85). Adapun pertimbangan dalam penentuan kriteria sampel pada penelitian ini adalah :

1. Saham tersebut terdaftar di Bursa Efek Indonesia (BEI) dan termasuk saham anggota indeks LQ-45 selama periode penelitian.

2. Berfluktuasi searah dengan indeks LQ-45 selama periode penelitian.

3. Aktif diperdagangkan selama periode penelitian.

4. Emiten tidak melakukan corporation action selama periode penelitian.

Tabel 1

Variabel Penelitian dan Pengukuran

\begin{tabular}{|c|c|c|c|c|}
\hline No & $\begin{array}{l}\text { Variabel } \\
\text { Penelitian }\end{array}$ & Definisi & Pengukuran & Skala \\
\hline 1. & $\begin{array}{l}\text { Pengumuman } \\
\text { hasil pemilihan } \\
\text { Presiden } \\
\text { Amerika } \\
\text { Serikat2016 } \\
\text { Donald Trump }\end{array}$ & $\begin{array}{l}\text { Peristiwa yang hendak } \\
\text { diuji kandungan } \\
\text { informasinya(Sumber: } \\
\text { Wibowo, 2017) }\end{array}$ & $\begin{array}{l}\text { Harga saham harian tanggal } 31 \\
\text { Oktober } 2016 \text { (t-7) sampai dengan } 18 \\
\text { November } 2016(t+7)\end{array}$ & Rasio \\
\hline 2. & Abnormal Return & $\begin{array}{l}\text { Selisih antara return } \\
\text { dengan return ekspektasi } \\
\text { realisasi (Sumber: } \\
\text { Jogiyanto, 2016) }\end{array}$ & RTNi,t = Ri,t $-E[R i, t]$ & Rasio \\
\hline 3. & Return Realisasi & $\begin{array}{l}\text { Return yang } \\
\text { sesungguhnya terjadi } \\
\text { (Sumber: Jogiyanto, 2016) }\end{array}$ & Rit $=\frac{(P i . t-P i . t-1)}{P i . t-1}$ & Rasio \\
\hline 4. & $\begin{array}{l}\text { Return } \\
\text { Ekspektasi } \\
\text { (market model) }\end{array}$ & $\begin{array}{l}\text { yang diharapkan akan } \\
\text { diperoleh investor masa } \\
\text { mendatang(Sumber: } \\
\text { Jogiyanto,2016) }\end{array}$ & TVA $=\frac{\text { jumlah saham i yang diperdagangkan pada waktu t }}{\text { jumlah saham i yang beredar pada waktu t }}$ & Rasio \\
\hline 5. & $\begin{array}{l}\text { Volume } \\
\text { Perdagangan } \\
\text { Saham Trading } \\
\text { volume activity) }\end{array}$ & $\begin{array}{l}\text { Perbandingan antara } \\
\text { jumlah saham yang } \\
\text { diperdagangkan dengan } \\
\text { jumlah saham yang } \\
\text { beredar(Sumber: Ningsih, } \\
2014 \text { dalam Arisyahidin, } \\
\text { 2012) }\end{array}$ & $\begin{array}{c}\text { Frekuensinya } \geq 75 \text { kali. (dikatakan aktif } \\
\text { diperdagangkan) }\end{array}$ & Rasio \\
\hline 6. & $\begin{array}{l}\text { Frekuensi } \\
\text { Perdagangan } \\
\text { Saham }\end{array}$ & $\begin{array}{l}\text { Berapa kali transaksi } \\
\text { jual beli terjadi pada } \\
\text { saham (Sumber: } \\
\text { Kurniawan, 2014) }\end{array}$ & & \\
\hline
\end{tabular}

Sumber : Data diolah peneliti (2017) 
HASIL DAN PEMBAHASAN ANALISIS HASIL PENGUMPULAN DATA

Data yang digunakan dalam penelitian ini merupakan data saham harian yang termasuk anggota indeks LQ45 yang terdaftar di Bursa Efek Indonesia (BEI), dalam periode penelitian selama 15 hari (kecuali hari sabtu dan minggu), yaitu dimulai pada tanggal 31 Oktober 2016 (t-7) sampai dengan 18 November $2016(t+7)$ dan tanggal pengumuman pemilihan Presiden Amerika Serikat 2016 yang jatuh tanggal 9 November 2016 sebagai (t0). Teknik pengumpulan data yang digunakan adalah teknik purposive sampling, yaitu berdasarkan kriteria yang telah ditentukan untuk menentukan sampel, dari 45 saham anggota indeks LQ45 yang terdaftar di Bursa Efek Indonesia hanya 24 perusahaan yang memenuhi kriteria tersebut. Proses pemilihan sampel dapat dilihat pada tabel 2 .

\section{Tabel 2}

\section{Proses Seleksi Sampel Berdasarkan} Kriteria

\begin{tabular}{|l|l|c|}
\hline No & Kriteria & Jumlah \\
\hline 1. & $\begin{array}{l}\text { Saham terdaftar di Bursa Efek } \\
\text { Indonesia (BEI). }\end{array}$ & 539 \\
\hline 2. & $\begin{array}{l}\text { Saham tidak termasuk anggota } \\
\text { indeks LQ45. }\end{array}$ & $(494)$ \\
\hline 3. & $\begin{array}{l}\text { Saham tidak Berfluktuasi searah } \\
\text { dengan indeks LQ45. }\end{array}$ & $(9)$ \\
\hline 4. & $\begin{array}{l}\text { Saham tidak aktif } \\
\text { diperdagangkan. }\end{array}$ & 0 \\
\hline 5. & $\begin{array}{l}\text { Emiten melakukan corporation } \\
\text { action }\end{array}$ & $(12)$ \\
\hline \multicolumn{2}{|c|}{ Perusahaan yang dijadikan sampel } & 24 \\
\hline \multicolumn{2}{|c|}{ Periode penelitian } & 15 \\
\hline \multicolumn{2}{|c|}{ Total observasi } & 360 \\
\hline
\end{tabular}

Sumber : Peneliti (2017)

Berdasarkan Tabel 2 dari 45 saham anggota indeks LQ45 dengan periode penelitian selama 15 hari, membentuk data panel yang dimiliki sebanyak 360 observasi $(24 \times 15)$.

\section{Hasil Penelitian}

Dalam penelitian ini terdapat beberapa tahapan dalam menjelaskan hasil penelitian untuk pengujian efisiensi pasar dan pengujian hipotesis. Pertama, untuk menggambarkan setiap variabel akan dijelaskan dalam statistik deskriptif. Kedua, melakukan uji normalitas data untuk melihat data berdistribusi normal. Kemudian dilakukan uji beda ( $t$-test) pada setiap variabel. Setelah memenuhi uji beda ( $t$-test) maka dilakukan penarikan kesimpulan.

\section{Pengujian Efisiensi Pasar}

Pengujian efisiensi pasar dalam penelitian ini merupakan pengujian efisiensi pasar bentuk setengah kuat (semistrong form). Hal ini dikarenakan informasi yang terkandung dalam pengumuman hasil pemilihan Presiden Amerika Serikat 2016 Donald Trump merupakan informasi yang dipublikasikan. Informasi tersebut akan mengakibatkan pergeseran harga saham menuju harga ekuilibrium yang baru. Jika pasar bereaksi dengan cepat untuk mencapai harga ekuilibrium yang baru, maka pasar tersebut merupakan pasar yang efisien. Sebaliknya jika pasar bereaksi dengan lambat, maka hal ini menunjukkan adanya asimetri informasi. Pasar yang demikian merupakan pasar yang tidak efisien. Pengujian ini dilakukan dengan cara menghitung abnormal return 24 saham yang digunakan sebagai sampel penelitian. Abnormal return dihitung selama 15 hari bursa, yaitu dari tanggal 31 Oktober $2016(t-7)$ sampai 18 Oktober $2016(t+7)$. Tahapan pertama, pengujian ini dengan 
menggunakan statistik deskriptif untuk menggmbarkan setiap variabel. Tahapan Kedua, melakukan uji normalitas untuk menentukan data berdistribusi normal menggunakan one-sample kolmogorovsmirnov z-test. Kemudian tahapan ketiga, melakukan uji beda ( $t$-test) dengan menggunakan one-sample t-test.

\section{Statistik Deksriptif}

Statistik deskriptif digunakan untuk mengetahui nilai maksimum, minimum, rata-rata (mean), dan standar deviasi pada variabel abnormal return selama periode penelitian. Pengujian statistik deskriptif terhadap variabel tersebut memperlihatkan hasil sebagai berikut :

Tabel 3

Statistik Deskriptif Abnormal return Pengujian Efisiensi Pasar Descriptive Statistics

\begin{tabular}{|l|c|c|c|c|c|}
\hline & $\mathrm{N}$ & $\begin{array}{c}\text { Mini- } \\
\text { mum }\end{array}$ & $\begin{array}{c}\text { Maxi- } \\
\text { mum }\end{array}$ & Mean & Deviation \\
\hline Oct_31 & 24 & -.02 & .04 & .0026 & .01474 \\
Nov_1 & 24 & -.06 & .04 & -.0030 & .02021 \\
Nov_2 & 24 & -.03 & .01 & -.0118 & .01302 \\
Nov_3 & 24 & -.03 & .04 & -.0013 & .01621 \\
Nov_4 & 24 & -.02 & .04 & .0038 & .01467 \\
Nov_7 & 24 & -.03 & .05 & -.0027 & .01794 \\
Nov_8 & 24 & -.06 & .03 & -.0036 & .01803 \\
Nov_9 & 24 & -.03 & .04 & .0063 & .01474 \\
Nov_10 & 24 & -.02 & .05 & .0052 & .01733 \\
Nov_11 & 24 & -.03 & .05 & .0023 & .01721 \\
Nov_14 & 24 & -.03 & .03 & .0003 & .01759 \\
Nov_15 & 24 & -.05 & .03 & -.0063 & .01932 \\
Nov_16 & 24 & -.04 & .08 & .0063 & .02658 \\
Nov_17 & 24 & -.05 & .05 & .0025 & .02447 \\
Nov_18 & 24 & -.03 & .02 & -.0006 & .01240 \\
Valid N & & & & & \\
(listwise) & 24 & & & & \\
\hline
\end{tabular}

Sumber: Output SPSS 22 (2017)
Tabel 3 menunjukkan bahwa ratarata abnormal return pada saat pengumuman hasil pemilihan Presiden Amerika Serikat 2016 Donald Trump adalah 0,0063 dengan standar deviasi 0,01474 . Rata a abnormal return tertinggi terjadi pada tanggal 9 November 2016 (t0) dengan nilai 0,0063 dan standar deviasi 0,01474 serta pada tanggal 16 November 2016 dengan nilai 0,0063 dan standar deviasi 0,02447. Rata-rata abnormal return terendah terjadi pada tanggal 18 November $2016(t+7)$ dengan nilai $-0,0006$ dan standar deviasi 0,01240.

\section{Uji Normalitas}

Uji normalitas digunakan untuk mengetahui distribusi data pada variabel abnormal return selama periode penelitian. Uji normalitas ini menggunakan one-sample kolmogorovsmirnov z-test. Dasar pengambilan keputusan adalah jika nilai signifikansi > 0,01 maka data tersebut berdistribusi normal. Sebaliknya, jika nilai signifikansi < 0,01 maka data tersebut tidak berdistribusi normal. Uji normalitas terhadap variabel tersebut memperlihatkan hasil sebagai berikut : 


\section{Tabel 4}

Uji Normalitas Abnormal Return Pengujian Efisiensi Pasar One-Sample Kolmogorov-Smirnov Test

\begin{tabular}{|c|c|c|c|c|c|c|c|c|c|c|c|c|c|c|c|c|}
\hline & & $\begin{array}{r}\text { Oct } \\
31\end{array}$ & $\begin{array}{c}\text { Nov } \\
1\end{array}$ & $\begin{array}{c}\text { Nov } \\
2\end{array}$ & $\begin{array}{c}\text { Nov } \\
3\end{array}$ & $\begin{array}{c}\text { Nov } \\
4\end{array}$ & $\begin{array}{c}\text { Nov } \\
7\end{array}$ & $\begin{array}{c}\text { Nov } \\
8\end{array}$ & $\begin{array}{c}\text { Nov } \\
9\end{array}$ & $\begin{array}{c}\text { Nov } \\
10\end{array}$ & $\begin{array}{r}\text { Nov } \\
11 \\
\end{array}$ & $\begin{array}{r}\text { Nov } \\
14\end{array}$ & $\begin{array}{r}\text { Nov } \\
15 \\
\end{array}$ & $\begin{array}{r}\text { Nov } \\
16 \\
\end{array}$ & $\begin{array}{r}\text { Nov } \\
17\end{array}$ & $\begin{array}{r}\text { Nov } \\
18 \\
\end{array}$ \\
\hline \multirow{5}{*}{$\begin{array}{l}\mathrm{N} \\
\text { Normal } \\
\text { Parameters } \\
\text { b }\end{array}$} & & 24 & 24 & 24 & 24 & 24 & 24 & 24 & 24 & 24 & 24 & 24 & 24 & 24 & 24 & 24 \\
\hline & Mea & 002 & & & & .003 & & & .006 & & & 000 & & 006 & 002 & \\
\hline & $\mathrm{n}$ & & $\begin{array}{r}.003 \\
0\end{array}$ & $\begin{array}{r}.011 \\
8\end{array}$ & $\begin{array}{r}.001 \\
3\end{array}$ & 8 & $\begin{array}{r}.002 \\
7\end{array}$ & $\begin{array}{r}.003 \\
6\end{array}$ & 3 & .0052 & .0023 & 3 & $\begin{array}{r}.006 \\
3\end{array}$ & 3 & 5 & -.0006 \\
\hline & & .014 & .020 & .013 & .016 & .014 & .017 & .018 & .014 & .0173 & .0172 & .017 & .019 & .026 & .024 & .0124 \\
\hline & ation & 74 & 21 & 02 & 21 & 67 & 94 & 03 & 74 & 3 & 1 & 59 & 32 & 58 & 47 & 0 \\
\hline \multirow{3}{*}{$\begin{array}{l}\text { Most } \\
\text { Extreme } \\
\text { Differences }\end{array}$} & $\begin{array}{l}\text { Abs } \\
\text { olute }\end{array}$ & .161 & .142 & .169 & .141 & .101 & .147 & .188 & .112 & .124 & .121 & .142 & .094 & .163 & .076 & .174 \\
\hline & $\begin{array}{l}\text { Posit } \\
\text { ive }\end{array}$ & .161 & .107 & .169 & .141 & .080 & .147 & .147 & .090 & .124 & .121 & .110 & .062 & .163 & .076 & .111 \\
\hline & $\begin{array}{l}\mathrm{Neg} \\
\text { ative }\end{array}$ & .076 & .142 & .161 & .107 & .101 & -.076 & -.188 & -.112 & -.065 & 81 & .142 & .094 & .120 & .066 & -.174 \\
\hline \multirow{2}{*}{\multicolumn{2}{|c|}{$\begin{array}{l}\text { Test Statistic } \\
\text { Asymp. Sig. (2- } \\
\text { tailed) }\end{array}$}} & .161 & .142 & .169 & .141 & .101 & .147 & .188 & .112 & .124 & .121 & .142 & .094 & .163 & .076 & .174 \\
\hline & & .109 & $.200^{c}$ & $.075^{\circ}$ & $\begin{array}{r}200 \\
\mathrm{c}, \mathrm{d}\end{array}$ & $\begin{array}{r}200 \\
\mathrm{c}, \mathrm{d}\end{array}$ & $.197^{\circ}$ & $.028^{c}$ & $.200^{\mathrm{C}}$ & $.200^{c, d}$ & $.200^{\mathrm{c}, \mathrm{d}}$ & $\begin{array}{r}200 \\
\mathrm{~cd}\end{array}$ & $\begin{array}{r}200 \\
. c, d\end{array}$ & .099 & $\begin{array}{r}200 \\
c, d\end{array}$ & $.057^{\circ}$ \\
\hline
\end{tabular}
a. Test distribution is Normal.
b. Calculated from data.
c. Lilliefors Significance Correction.
d. This is a lower bound of the true significance.

Sumber : Output SPSS 22 (2017)

Tabel 4 menunjukkan bahwa nilai signifikansi pada variabel abnormal return selama periode penelitian $>0,01$. Oleh karena itu nilai signifikansi $>0,01$ maka dapat disimpulkan bahwa data pada variabel tersebut berdistribusi normal. Dengan demikian, analisis dalam pengujian ini dapat dilanjutkan dalam statistika parametrik menggunakan onesample t-test.

\section{Uji Beda (t-Test)}

Uji beda (t-test) digunakan untuk menguji rata-rata abnormal return selama periode penelitian. Uji beda ( $t$ test) ini menggunakan one-sample t-test. Dasar pengambilan keputusan adalah jika nilai signifikansi < 0,05 maka ratarata abnormal return tidak sama dengan nol, artinya terdapat reaksi pasar yang signifikan. Sebaliknya, jika nilai signifikansi > 0,05 maka rata-rata abnormal return sama dengan nol, artinya tidak terdapat reaksi pasar yang signfikan. Uji beda ( $t$-test) terhadap ratarata abnormal return selama periode penelitian memperlihatkan hasil sebagai berikut :

Tabel 5 menunjukkan bahwa reaksi pasar yang signifikan terjadi pada tanggal 2 November 2016 (t-5) dan 9 November 2016 (t0). Hal ini ditunjukkan dengan rata-rata abnormal return tanggal 2 November 2016 adalah 0,01180 dengan nilai signifikansi 0,000 serta rata-rata abnormal return tanggal 9 November 2016 adalah 0,00628 dengan nilai signifikansi 0,048 . Oleh karena nilai signifikansi pada kedua tanggal tersebut $<$ 0,05 maka dapat disimpulkan bahwa rata-rata abnormal return pada kedua tanggal tersebut tidak sama dengan nol, artinya terdapat reaksi pasar yang signifikan pada kedua tanggal tersebut. 
Tabel 5

Uji Beda ( $t$-Test) Abnormal return Pengujian Efisiensi Pasar

One-Sample Test

\begin{tabular}{|c|c|c|c|c|c|c|}
\hline & \multicolumn{6}{|c|}{ Test Value $=0$} \\
\hline & \multirow[b]{2}{*}{$\mathrm{T}$} & \multirow[b]{2}{*}{ DF } & \multirow{2}{*}{$\begin{array}{l}\text { Sig. (2- } \\
\text { tailed) }\end{array}$} & \multirow{2}{*}{$\begin{array}{l}\text { Mean } \\
\text { Diffe- } \\
\text { rence }\end{array}$} & \multicolumn{2}{|c|}{$\begin{array}{l}95 \% \text { Confidence } \\
\text { Interval of the } \\
\text { Difference }\end{array}$} \\
\hline & & & & & Lower & Upper \\
\hline Oct_31 & .875 & 23 & .391 & .00263 & -.0036 & .0089 \\
\hline Nov_1 & -.727 & 23 & .474 & -.00300 & -.0115 & .0055 \\
\hline Nov_2 & -4.442 & 23 & .000 & -.01180 & -.0173 & -.0063 \\
\hline Nov_3 & -.382 & 23 & .706 & -.00126 & -.0081 & .0056 \\
\hline Nov_4 & 1.280 & 23 & .213 & .00383 & -.0024 & .0100 \\
\hline Nov_7 & -.738 & 23 & .468 & -.00270 & -.0103 & .0049 \\
\hline Nov_8 & -.976 & 23 & .339 & -.0 & -.0112 & .0040 \\
\hline Nov_9 & 2.086 & 23 & .048 & .00628 & .0001 & .0125 \\
\hline Nov_10 & 1.465 & 23 & .157 & .00518 & -.0021 & .0125 \\
\hline Nov_11 & .644 & 23 & .526 & .00226 & -.0050 & .0095 \\
\hline Nov_14 & .091 & 23 & .928 & .00033 & -.0071 & .0078 \\
\hline Nov_15 & -1.597 & 23 & .124 & -.00630 & -.0145 & .0019 \\
\hline Nov_16 & 1.160 & 23 & .258 & .00629 & -.0049 & .0175 \\
\hline Nov_17 & .500 & 23 & .621 & .00250 & -.0078 & .0128 \\
\hline Nov_18 & -.256 & 23 & .800 & -.00065 & -.0059 & .0046 \\
\hline
\end{tabular}

Sumber: Output SPSS 22 (2017) asumsi bila data berdistribusi normal menggunakan statistik parametrik uji paired sample t-test dan bila data tidak berdistribusi normal menggunakan statistik non parametrik uji wilcoxon signed rank tes. Setelah memenuhi uji hipotesis maka dilakukan penarikan kesimpulan.

\section{Statistik Deskriptif}

1. Analisis Statistik Deskriptif Abnormal Return

Hasil analisis statistik deskriptif untuk variabel abnormal return sebelum, pengumuman dan sesudah pengumuman hasil pemilihan Presiden Amerika Serikat 2016 Donald Trump disajikan pada tabel 6 sebagai berikut:

\section{Tabel 6}

Statistik Deskriptif Abnormal

return

Descriptive Statistics

\section{Pengujian Hipotesis}

Dalam penelitian ini terdapat beberapa tahapan dalam menjelaskan hasil penelitian dengan data rata-rata harian yang digunakan dari tanggal 31 oktober 2016 - 8 November 2016 (t-7) sebelum peristiwa dan dari tanggal 10 November 2016 - 18 November 2016 $(t+7)$ setelah peristiwa. Tahapan pertama, untuk menggambarkan setiap variabel akan dijelaskan dalam analisis deskriptif dengan tambahan data ratarata harian tanggal 9 November 2016 (to) sebagai tanggal pengumuman terpilihnya Presiden Amerika Serikat yang digunakan untuk melihat rata-rata (mean). Tahapan kedua, melakukan uji normalitas data untuk menentukan data berdistribusi normal dan tidak berdistribusi normal menggunakan shapiro-wilk test. Kemudian tahapan ketiga, dilakukan uji beda ( $t$-test) dengan

\begin{tabular}{|l|c|c|c|c|c|}
\hline & $\mathrm{N}$ & $\begin{array}{c}\text { Mini- } \\
\text { mum }\end{array}$ & $\begin{array}{c}\text { Maxi- } \\
\text { mum }\end{array}$ & $\begin{array}{c}\text { Mean } \\
\text { Deviation }\end{array}$ \\
\hline AR_Sebelum & 24 & -.01 & .00 & -.0023 & .00378 \\
Pengumuman & 24 & -.03 & .04 & .0063 & .01474 \\
AR_Sesudah & 24 & -.01 & .01 & .0014 & .00375 \\
Valid N & & & & & \\
(listwise) & 24 & & & & \\
& & & & & \\
\hline
\end{tabular}

Sumber : Output SPSS 22 (2017)

Tabel 6 di atas memperlihatkan ratarata (mean) dan standar deviasi dari variabel abnormal return, sebagai berikut:

1) Rata-rata abnormal return sebelum pengumuman hasil pemilihan Presiden Amerika Serikat 2016 Donald Trump sebesar $-0,0023$ dengan standar deviasi sebesar 0,00378.

2) Rata-rata abnormal return pada saat pengumuman hasil pemilihan Presiden Amerika Serikat 2016 
Donald Trump 0,0063 dengan standar deviasi 0,01474.

3) Rata-rata abnormal return sesudah pengumuman hasil pemilihan Presiden Amerika Serikat 2016 Donald Trump sebesar 0,0014 dengan standar deviasi sebesar 0,00375.

2. Analisis Statistik Deskriptif Aktivitas Volume Perdagangan Saham

Hasil analisis statistik deskriptif untuk variabel aktivitas volume perdagangan saham (trading volume activity) sebelum, pengumuman dan sesudah pengumuman hasil pemilihan Presiden Amerika Serikat 2016 Donald Trump disajikan pada tabel 7 sebagai berikut :

\section{Tabel 7}

\section{Statistik Deskriptif Volume Perdagangan Saham Descriptive Statistics}

\begin{tabular}{|l|c|c|c|c|c|}
\hline & $\mathrm{N}$ & $\begin{array}{c}\text { Mini- } \\
\text { mum }\end{array}$ & $\begin{array}{c}\text { Maxi- } \\
\text { mum }\end{array}$ & $\begin{array}{c}\text { Std. } \\
\text { Mean }\end{array}$ & Deviation \\
\hline TVA_Seebelum & 24 & .00 & .02 & .0019 & .00338 \\
Pengumuman & 24 & .00 & .02 & .0022 & .00409 \\
TVA_Sesudah & 24 & .00 & .01 & .0018 & .00196 \\
Valid N & & & & & \\
(listwise) & 24 & & & & \\
& & & & & \\
\hline
\end{tabular}

Sumber : Output SPSS 22 (2017)

Tabel 7 di atas memperlihatkan ratarata (mean) dan standar deviasi dari variabel aktivitas volume perdagangan saham, sebagai berikut :

1) Rata-rata volume perdagangan saham sebelum pengumuman hasil pemilihan Presiden Amerika Serikat 2016 Donald Trump sebesar 0,0019 dengan standar deviasi sebesar 0,00338 .

2) Rata-rata volume perdagangan saham pada saat pengumuman hasil pemilihan Presiden Amerika Serikat
2016 Donald Trump sebesar 0,0022 dengan standar deviasi sebesar 0,00409 .

3) ata-rata volume perdagangan saham sesudah pengumuman hasil pemilihan Presiden Amerika Serikat 2016 Donald Trump sebesar 0,0018 dengan standar deviasi sebesar 0,00196 .

3. Analisis Statistik Deskriptif Aktivitas Frekuensi Perdagangan Saham

Hasil analisis statistik deskriptif untuk variabel aktivitas frekuensi perdagangan saham sebelum, pengumuman dan sesudah pengumuman hasil pemilihan Presiden Amerika Serikat 2016 Donald Trump disajikan pada tabel 8 sebagai berikut:

\section{Tabel 8}

Statistik Deskriptif Frekuensi Perdagangan Saham Descriptive Statistics

\begin{tabular}{|l|c|c|c|c|}
\hline & $\begin{array}{c}\text { Mini- } \\
\text { mum }\end{array}$ & $\begin{array}{c}\text { Maxi- } \\
\text { mum }\end{array}$ & Mean & $\begin{array}{c}\text { Std. } \\
\text { Deviation }\end{array}$ \\
\hline $\begin{array}{l}\text { FR_Sebe- } \\
\text { lum } \\
\begin{array}{l}\text { Pengu- } \\
\text { muman } \\
\text { FR_Sesu- } \\
\text { dah } \\
\text { Valid N } \\
\text { (listwise) }\end{array}\end{array}$ & 369.14 & 12243.57 & 4027.8754 & 2503.00917 \\
\hline
\end{tabular}

Sumber : Output SPSS 22 (2017)

Tabel 8 di atas memperlihatkan ratarata (mean) dan standar deviasi dari variabel frekuensi perdagangan saham, sebagai berikut :

1) Rata-rata frekuensi perdagangan saham sebelum pengumuman hasil pemilihan Presiden Amerika Serikat 2016 Donald Trump sebesar $4.027,8754$ dengan standar deviasi sebesar $2.503,00917$. 
2) Rata-rata frekuensi perdagangan saham pada saat pengumuman hasil pemilihan Presiden Amerika Serikat 2016 Donald Trump sebesar $3.379,2500$ dengan standar deviasi sebesar 2.327,17902.

3) Rata-rata frekuensi perdagangan saham sesudah pengumuman hasil pemilihan Presiden Amerika Serikat 2016 Donald Trump sebesar $3.149,1487$ dengan standar deviasi sebesar $2.074,37926$.

\section{Uji Normalitas}

\section{Uji Normalitas Abnormal Return}

Uji normalitas terhadap data ratarata abnormal return sebelum dan sesudah pengumuman hasil pemilihan Presiden Amerika Serikat 2016 Donald Trump disajikan pada tabel 9 sebagai berikut :

\section{Tabel 9}

Hasil Uji Normalitas Abnormal Return Sebelum dan Sesudah Pengumuman Hasil Pemilihan Presiden Amerika Serikat 2016 Donald Trump Tests of Normality

\begin{tabular}{|l|c|c|c|c|c|c|}
\hline & \multicolumn{3}{|c|}{ Kolmogorov-Smirnov $^{\mathrm{a}}$} & \multicolumn{3}{c|}{ Shapiro-Wilk } \\
\hline & Statistic & Df & Sig. $^{*}$ & Statistic & df & Sig. \\
\hline AR_Sebelum & .110 & 24 & $.200^{*}$ & .962 & 24 & .487 \\
\hline AR_Sesudah & .153 & 24 & .154 & .942 & 24 & .185 \\
\hline
\end{tabular}

*. This is a lower bound of the true significance.

a. Lilliefors Significance Correction Sumber: Output SPSS 22 (2017)

Tabel 9 menunjukkan bahwa pada variabel abnormal return sebelum dan sesudah pengumuman hasil pemilihan Presiden Amerika Serikat 2016 Donald Trump menunjukkan signifikasi sebesar 0.487 dan 0.185. Penggunaan uji normalitas shapiro-wilk test didasarkan karena sampel < 50. Berdasarkan krtiteria pengujian yang telah ditentukan, maka data rata-rata abnormal return adalah berdistribusi normal karena Sig. rata-rata abnormal return > (5\%). Dengan demikian, untuk pengujian hipotesis pertama dapat dilanjutkan dalam uji parametrik menggunakan paired-samples t-test.

2. Uji Normalitas Aktivitas Volume Perdagangan Saham

Uji normalitas terhadap data ratarata aktivitas volume perdagangan saham (trading volume activity) sebelum dan sesudah pengumuman hasil pemilihan Presiden Amerika Serikat 2016 Donald Trump disajikan pada tabel 10 sebagai berikut:

\begin{tabular}{|c|c|c|c|c|c|c|}
\hline \multicolumn{7}{|c|}{$\begin{array}{c}\text { Tabel } 10 \\
\text { Hasil Uji Normalitas Volume } \\
\text { Perdagangan Saham Sebelum dan } \\
\text { Sesudah Pengumuman Hasil Pemilihan } \\
\text { Presiden Amerika Serikat } 2016 \\
\text { Donald Trump } \\
\text { Tests of Normality }\end{array}$} \\
\hline & \multicolumn{3}{|c|}{ Kolmogorov-Smirnov } & \multicolumn{3}{|c|}{ Shapiro-Wilk } \\
\hline & Statistic & Df & Sig. & Statistic & $\mathrm{df}$ & Sig. \\
\hline TVA_Sebelum & .343 & 24 & .000 & .508 & 24 & .000 \\
\hline TVA_Sesudah & .271 & 24 & .000 & .726 & 24 & .000 \\
\hline
\end{tabular}

Tabel 10 menunjukkan bahwa pada variabel aktivitas volume perdagangan saham sebelum dan sesudah pengumuman hasil pemilihan Presiden Amerika Serikat 2016 Donald Trump menunjukkan signifikasi sebesar 0.000 dan 0.000. Penggunaan uji normalitas shapiro-wilk test didasarkan karena sampel < 50. Berdasarkan krtiteria pengujian yang telah ditentukan, maka data rata-rata volume perdagangan 
saham adalah tidak berdistribusi normal karena Sig. rata-rata volume perdagangan saham < $(5 \%)$. Dengan demikian, untuk pengujian hipotesis kedua dapat dilanjutkan dalam uji nonparametrik menggunakan wilcoxon signed rank test.

3. Uji Normalitas Aktivitas Frekuensi Perdagangan Saham

Uji normalitas terhadap data ratarata aktivitas frekuensi perdagangan saham sebelum dan sesudah pengumuman hasil pemilihan Presiden Amerika Serikat 2016 Donald Trump disajikan pada tabel 11 sebagai berikut :

Tabel 11

Hasil Uji Normalitas Frekuensi

Perdagangan Saham Sebelum dan

Sesudah Pengumuman Hasil Pemilihan

Presiden Amerika Serikat 2016

Donald Trump

Tests of Normality

\begin{tabular}{|l|c|c|c|c|c|c|}
\hline & \multicolumn{3}{|c|}{$\begin{array}{c}\text { Kolmogorov- } \\
\text { Smirnov }\end{array}$} & \multicolumn{3}{c|}{ Shapiro-Wilk } \\
\hline & Statistic & Df & Sig. & Statistic & Df & Sig. \\
\hline FR_Sebelum & .154 & 24 & .148 & .892 & 24 & .015 \\
\hline FR_Sesudah & .169 & 24 & .075 & .843 & 24 & .002 \\
\hline
\end{tabular}

a. Lilliefors Significance Correction

Sumber : Output SPSS 22 (2017)

Tabel 11 menunjukkan bahwa pada variabel aktivitas frekuensi perdagangan saham sebelum dan sesudah pengumuman hasil pemilihan Presiden Amerika Serikat 2016 Donald Trump menunjukkan signifikasi sebesar 0.015 dan 0.002. Penggunaan uji normalitas shapiro-wilk test didasarkan karena sampel $<50$ Berdasarkan krtiteria pengujian yang telah ditentukan, maka data ratarata frekuensi perdagangan saham adalah tidak berdistribusi normal karena Sig. rata-rata frekuensi perdagangan saham < $(5 \%)$. Dengan demikian, untuk pengujian hipotesis ketiga dapat dilanjutkan dalam uji non-parametrik menggunakan wilcoxon signed rank test.

\section{Uji Beda (t-Test)}

\section{Uji Beda (t-Test) Abnormal Return}

Pengujian pada hipotesis pertama pada variabel abnormal return menggunakan uji dengan paired sample ttest karena data berdistribusi normal sesuai dengan hasil uji normalitas. Pengujian ini dilakukan untuk mengetahui apakah terdapat perbedaan rata-rata abnormal return sebelum dan sesudah pengumuman hasil pemilihan Presiden Amerika Serikat 2016 Donald Trump. Dasar pengambilan keputusan adalah sebagai berikut :

1. Ho1: Tidak terdapat perbedaan yang signifikan antara abnormal return pada saat sebelum dan sesudah pengumuman hasil pemilihan Presiden Amerika Serikat 2016 Donald Trump.

2. Ha1: Terdapat perbedaan yang signifikan antara abnormal return pada saat sebelum dan sesudah pengumuman hasil pemilihan Presiden Amerika Serikat 2016 Donald Trump.

Dengan menggunakan tingkat signifikasi sebesar $5 \%$, jika nilai (Asymp.Sig) $>0.0,5$ maka Ho1 diterima, artinya tidak terdapat perbedaan abnormal return sebelum dan sesudah pengumuman hasil pemilihan Presiden Amerika Serikat 2016 Donald Trump. Sebaliknya, jika nilai (Asymp.Sig) < 0,005 maka Ha1 diterima, artinya terdapat perbedaan abnormal 
return sebelum dan sesudah pengumuman hasil pemilihan Presiden Amerika Serikat 2016 Donald Trump.

Hasil uji paired sample t-test terhadap perbedaan rata-rata abnormal return sebelum dan sesudah pengumuman hasil pemilihan Presiden Amerika Serikat 2016 Donald Trump memperlihatkan hasil sebagai berikut :

Pada Tabel 12 uji signifikasi dilakukan dengan membandingkan sig. (2-tailed) dengan . Hasil pengujian pada tabel menunjukkan bahwa nilai (Asymp.Sig) < $(0,021<0,05)$, maka dikatakan terdapat perbedaan abnormal return. Berdasarkan hasil analisis tersebut dapat disimpulkan bahwa $\mathrm{Ha} 1$ diterima dan Ho1 ditolak, artinya terdapat perbedaan abnormal return sebelum dan sesudah pengumuman hasil pemilihan Presiden Amerika Serikat 2016 Donald Trump.

Tabel 12

Hasil Uji Paired Sample T-test Abnormal return Sebelum dan Sesudah Pengumuman Hasil Pemilihan Presiden Amerika Serikat 2016 Donald Trump Paired Samples Test

\begin{tabular}{|c|c|c|c|c|c|c|c|c|}
\hline & \multicolumn{5}{|c|}{ Paired Differences } & \multirow[b]{2}{*}{$\mathrm{T}$} & \multirow[b]{2}{*}{ DF } & \multirow[b]{2}{*}{$\begin{array}{l}\text { Sig. (2- } \\
\text { tailed) }\end{array}$} \\
\hline & Mean & $\begin{array}{c}\text { Std. } \\
\text { Deviation }\end{array}$ & $\begin{array}{c}\text { Std. Error } \\
\text { Mean }\end{array}$ & $\begin{array}{r}95 \% \mathrm{C} \\
\text { Interv } \\
\text {-Diff }\end{array}$ & $\begin{array}{l}\text { nidence } \\
\text { l of the } \\
\text { rence }\end{array}$ & & & \\
\hline & & & & & & & & \\
\hline I 1 AR_Sesudah & .00364 & .00723 & .00148 & -.00670 & -.00059 & 2.469 & 23 & .021 \\
\hline
\end{tabular}

Sumber: Output SPSS 22 (2017)

2. Uji Beda (t-Test) Aktivitas Volume Perdagangan Saham

Pengujian pada hipotesis kedua pada variabel aktivitas volume perdagangan saham menggunakan uji dengan wilcoxon signed rank test karena data tidak berdistribusi normal sesuai dengan hasil uji normalitas. Pengujian ini dilakukan untuk mengetahui apakah terdapat perbedaan rata-rata aktivitas volume perdagangan saham (trading volume activity) sebelum dan sesudah pengumuman hasil pemilihan Presiden Amerika Serikat 2016 Donald Trump.

1. Ho2 : Tidak terdapat perbedaan yang signifikan antara aktivitas volume perdagangan saham (trading volume activity) pada saat sebelum dan sesudah pengumuman hasil pemili- han Presiden Amerika Serikat 2016 Donald Trump.

2. Ha2 : Terdapat perbedaan yang signifikan antara aktivitas volume perdagangan saham (trading volume activity) pada saat sebelum dan sesudah pengumuman hasil pemilihan Presiden Amerika Serikat 2016 Donald Trump.

Dengan menggunakan tingkat signifikasi ( ) sebesar $5 \%$, jika nilai (Asymp.Sig) > 0.0,5 maka Ho2 diterima, artinya tidak terdapat perbedaan aktivitas volume perdagangan saham sebelum dan sesudah pengumuman hasil pemilihan Presiden Amerika Serikat 2016 Donald Trump. Sebaliknya, jika nilai (Asymp.Sig) < 0,005 maka Ha2 diterima, 
artinya terdapat perbedaan aktivitas volume perdagangan saham sebelum dan sesudah pengumuman hasil pemilihan Presiden Amerika Serikat 2016 Donald Trump.

Hasil uji wilcoxon signed rank test terhadap perbedaan rata-rata aktivitas volume perdagangan saham (trading volume activity) sebelum dan sesudah pengumuman hasil pemilihan Presiden Amerika Serikat 2016 Donald Trump memperlihatkan hasil sebagai berikut :

Tabel 13

Hasil Uji Wilcoxon Signed Rank Test Volume Perdagangan Saham Sebelum dan Sesudah Pengumuman Hasil Pemilihan Presiden Amerika Serikat 2016 Donald Trump Test Statistics $^{\mathrm{a}}$

\begin{tabular}{|l|l|}
\hline & $\begin{array}{l}\text { TVA_Sesudah - } \\
\text { TVA_Sebelum }\end{array}$ \\
\hline$Z$ & $-2.129^{\mathrm{b}}$ \\
Asymp. Sig. (2-tailed) & .033 \\
\hline
\end{tabular}

a. Wilcoxon Signed Ranks Test

b. Based on negative ranks.

Sumber : Output SPSS 22 (2017)

Pada tabel 13 uji signifikasi dilakukan dengan membandingkan sig. (2-tailed) dengan hasil pengujian pada tabel menunjukkan bahwa nilai (Asymp.Sig) < $(0,033<0,05)$, maka dikatakan terdapat perbedaan aktivitas volume perdagangan saham (trading volume activity). Berdasarkan hasil analisis tersebut dapat disimpulkan bahwa Ha2 diterima dan $\mathrm{Ho} 2$ ditolak, artinya terdapat perbedaan aktivitas volume perdagangan saham (trading volume activity) sebelum dan sesudah pengumuman hasil pemilihan Presiden Amerika Serikat 2016 Donald Trump.
3. Uji Beda (t-Test) Aktivitas Frekuensi Perdagangan Saham

Pengujian pada hipotesis ketiga pada variabel aktivitas frekuensi perdagangan saham menggunakan uji dengan wilcoxon signed rank test karena data tidak berdistribusi normal sesuai dengan hasil uji normalitas. Pengujian ini dilakukan untuk mengetahui apakah terdapat perbedaan rata-rata aktivitas frekuensi perdagangan saham sebelum dan sesudah pengumuman hasil pemilihan Presiden Amerika Serikat 2016 Donald Trump.

1. Ho3 : Tidak terdapat perbedaan yang signifikan antara aktivitas frekuensi perdagangan saham pada saat sebelum dan sesudah pengumuman hasil pemilihan Presiden Amerika Serikat 2016 Donald Trump.

2. Ha3 : Terdapat perbedaan yang signifikan antara aktivitas frekuensi perdagangan saham pada saat sebelum dan sesudah pengumuman hasil pemilihan Presiden Amerika Serikat 2016 Donald Trump.

Dengan menggunakan tingkat signifikasi ( ) sebesar 5\%, jika nilai (Asymp.Sig) > 0.0,5 maka $\mathrm{Ho3}$ diterima, artinya tidak terdapat perbedaan aktivitas frekuensi perdagangan saham sebelum dan sesudah pengumuman hasil pemilihan Presiden Amerika Serikat 2016 Donald Trump. Sebaliknya, jika nilai (Asymp.Sig) < 0,005 maka Ha3 diterima, artinya terdapat perbedaan aktivitas frekuensi perdagangan saham sebelum dan sesudah pengumuman hasil pemilihan Presiden Amerika Serikat 2016 Donald Trump.

Hasil uji wilcoxon signed rank test terhadap perbedaan rata-rata aktivitas frekuensi perdagangan saham sebelum dan sesudah pengumuman hasil pemilihan Presiden Amerika Serikat 2016 
Donald Trump memperlihatkan hasil sebagai berikut:

Tabel 14

Hasil Uji Wilcoxon Signed Rank Test

Frekuensi Perdagangan Saham

Sebelum dan Sesudah Pengumuman

Hasil Pemilihan Presiden Amerika

Serikat 2016 Donald Trump

Test Statistics $^{\mathrm{a}}$

\begin{tabular}{|l|l|}
\hline & FR_Sesudah - \\
& FR_Sebelum \\
\hline Z & $-2.714^{\mathrm{b}}$ \\
Asymp. Sig. (2-tailed) & 007 \\
\hline
\end{tabular}

a. Wilcoxon Signed Ranks Test

b. Based on positive ranks.

Sumber: Output SPSS 22 (2017)

Pada tabel 14 uji signifikasi dilakukan dengan membandingkan sig. (2-tailed) dengan hasil pengujian pada tabel menunjukkan bahwa nilai (Asymp.Sig) < $(0,007<0,05)$, maka dikatakan terdapat perbedaan aktivitas frekuensi perdagangan saham. Berdasarkan hasil analisis tersebut dapat disimpulkan bahwa Ha3 diterima dan Ho3 ditolak, artinya terdapat perbedaan aktivitas frekuensi perdagangan saham sebelum dan sesudah pengumuman hasil pemilihan Presiden Amerika Serikat 2016 Donald Trump.

\section{PEMBAHASAN}

Pada bagian ini akan membahas mengenai hasil pengujian efisiensi pasar dan pengujian hipotesis secara statistik dan analisisnya. Pembahasan mencakup analisis perbedaan setiap variabel dependen terhadap variabel independen serta pengaruhmya

\section{Pengujian Efisiensi Pasar}

Hasil pengujian efisiensi pasar menunjukkan bahwa reaksi pasar yang signifikan terjadi pada tanggal 2 November 2016 (t-5) dan 9 November 2016 (to). Hal ini ditunjukkan dengan nilai signifikansi rata-rata abnormal return pada kedua tanggal tersebut < 0,05 . Rata-rata abnormal return tanggal 2 November 2016 bernilai negatif $(-0,0118)$ sedangkan rata-rata abnormal return tanggal 9 November 2016 bernilai positif $(0,0063)$.

Reaksi pasar yang signifikan pada tanggal 2 November $2016 \quad(t-5)$ menunjukkan bahwa informasi yang terkandung dalam pengumuman hasil pemilihan Presiden Amerika Serikat 2016 Donald Trump sudah bocor ke publik. Informasi tersebut adalah mengenai kebijakan yang dikeluarkan pada masa kampanye dari calon Presiden Donald trump yang mengeluarkan kebijakan yang pro kontra bagi sejumlah kalangan yang berdampaknya terhadap perekonomian secara global dan banyaknya media masa yang mengikuti peristiwa pemilihan tersebut. Bocornya informasi tersebut ditunjukkan dengan rata-rata abnormal return yang bernilai negatif dan signifikan pada tanggal 2 November 2016. Rata-rata abnormal return yang bernilai negatif menunjukkan bahwa informasi kemenangan Donald Trump dianggap sebagai berita buruk (bad news).

Adapun reaksi pasar yang signifikan pada tanggal 9 November 2016 (to) merupakan reaksi pasar pada saat pengumuman hasil pemilihan Presiden Amerika Serikat 2016 Donald Trump. Reaksi ini berkebalikan dengan reaksi pada saat bocornya informasi kemenangan Donald Trump. Pasar bereaksi negatif pada saat bocornya informasi kemenangan Donald Trump, namun berbalik positif pada saat pengumuman. Hal ini ditunjukkan dengan rata-rata abnormal return bernilai 
positif dan signifikan pada tanggal 9 November 2016. Ada kemungkinan investor telah mengambil strategi pada saat terpilihnya Donald Trump sebagai Presiden Amerika Serikat seperti menunggu dan melihat kebijakankebijakan yang dikeluarkan oleh Donald Trump tersebut berjalan. Dengan demikian, reaksi pasar positif pada tanggal 9 November 2016 (t0) dianggap sebagai berita baik (good news).

Secara keseluruhan, berdasarkan hasil uji beda ( $t$-test) menggunakan onesample t-test, maka dapat disimpulkan bahwa pasar modal di Indonesia termasuk pasar yang efisien dalam bentuk setengah kuat (semistrong form). Hal ini dikarenakan pasar bereaksi dengan cepat dan tidak berkepanjangan (Jogiyanto, 2016).

\section{Pengujian Hipotesis}

Hasil penelitian ini menunjukkan bahwa terdapat perbedaan rata-rata abnormal return, aktivitas volume perdagangan saham (trading volume activity), dan aktivitas frekuensi perdagangan saham sebelum dan sesudah pengumuman hasil pemilihan Presiden Amerika Serikat 2016 Donald Trump.

\section{Pengaruh Pengumuman Hasil Pemilihan Presiden Amerika Serikat 2016 Donald Trump Terhadap Abnormal Return}

Berdasarkan uji Berdasarkan hasil pengujian abnormal return dengan uji paired sample t-test, maka diperoleh nilai (Asymp.Sig) $<(0,021<0,05)$. Nilai ini jelas lebih kecil dari 0,05 yang berarti mengindikasikan bahwa terdapat perbedaan abnormal return saham indeks LQ45 sebelum dan sesudah pengumuman hasil pemilihan Presiden Amerika Serikat 2016 Donald Trump.

Kesimpulan diambil dengan mempertimbangkan kajian teori dan emperis. Secara teoritis, abnormal return merupakan kelebihan dari imbal hasil yang sesungguhnya terjadi (actual return) terhadap imbal hasil normal. Imbal hasil normal merupakan imbal hasil ekspektasi (expected return) atau imbal hasil yang diharapkan oleh investor (Jogiyanto, 2016). Dapat disimpulkan bahwa imbal hasil tidak normal (abnormal return) adalah selisih antara imbal hasil sesungguhnya yang terjadi dengan imbal hasil ekspektasi. Apabila suatu peristiwa tidak menimbulkan suatu abnormal return, berarti para investor tidak bereaksi atau tidak ada reaksi pasar, karena reaksi oleh para investor terhadap informasi yang baru ditunjukkan oleh abnormal return (Jogiyanto, 2016). Begitu juga sebaliknya, jika abnormal return signifikan maka para investor bereaksi pada peristiwa maka para investor bereaksi pada kebijakan atau peristiwa tersebut. Terjadinya peristiwa pengumuman hasil pemilihan Presiden Amerika Serikat 2016 Donald Trump memberikan sinyal tentang adanya informasi buruk terhadap aktivitas bursa atau pergerakan harga saham yang menurun, dimana akan menimbulkan risiko bagi para investor dan bagi investasinya. Hal ini dapat dilihat dari perubahan rata-rata abnormal return sebelum, saat, dan sesudah pengumuman dimana reaksi pasar negatif sebelum peristiwa pengumuman hasil pemilihan Presiden Amerika Serikat 2016 Donald Trump hal ini disebabkan terjadinya penurunan rata-rata abnormal return yang kemudian terjadi reaksi pasar yang positif menjelang pengumuman yang ditunjukkan dengan naiknya rata- 
rata abnormal return yang mengindikasi kandungan informasi pemilihan Presiden Amerika Serikat tersebut memberi kabar baik (good news) namun sesudah pengumuman terpilihnya Donald Trump sebagai Presiden Amerika Serikat reaksi pasar kembali negatif dikarenakan informasi pemilihan tersebut memberi kabar buruk (bad news) yang ditunjukkan dengan menurunnya rata-rata abnormal return yang disebabkan oleh para investor beramai-ramai melakukan profit tracking (ambil untung) dan beberapa investor beralasan menghindari situasi yang tidak menentu akibat kebijakan proteksionisme Donald Trump juga adanya investor asing Amerika Serikat yang menarik dananya setelah terpilihnya Donald Trump untuk berinvestasi dinegaranya.

Hasil pengujian ini konsisten dengan hasil penelitian yang dilakukan oleh Soraya (2010), Yuwono (2013) dan Wibowo (2017). Hasil penelitianpenelitian tersebut menunjukkan terdapat perbedaan rata-rata aktivitas abnormal return yang signifikan sebelum dan sesudah peristiwa.

\section{Pengaruh Pengumuman Hasil Pemilihan Presiden Amerika Serikat 2016 Donald Trump Terhadap Aktivitas Volume Perdagangan Saham}

Berdasarkan uji Berdasarkan hasil pengujian aktivitas volume perdagangan saham (trading volume activity) dengan uji wilcoxon signed rank test, maka diperoleh nilai (Asymp.Sig) < $(0,033<$ $0,05)$. Nilai ini jelas lebih kecil dari 0,05 yang berarti mengindikasikan bahwa terdapat perbedaan aktivitas volume perdagangan saham (trading volume activity) indeks LQ45 sebelum dan sesudah pengumuman hasil pemilihan
Presiden Amerika Serikat 2016 Donald Trump.

Adanya perbedaan rata-rata aktivitas volume perdagangan saham yang signifikan sebelum dan sesudah kebijakan-kebijakan yang dikeluarkan oleh Donald Trump (trump effect) yang memberikan sinyal tentang adanya informasi buruk terhadap aktivitas bursa yang berdampak pada perekonomian di berbagai negara di Asia termasuk Indonesia yang mempengaruhi penurunan rata-rata aktivitas volume perdagangan saham atau jumlah lembar saham yang diperdagangkan secara harian. Hal ini bisa dilihat perbedaan rata-rata aktivitas volume perdagangan saham sebelum, saat, dan sesudah dimana sebelum peristiwa rata-rata aktivitas volume perdagangan saham atau jumlah lembar saham masih diminati oleh para investor yang ditunjukkan dengan meningkatnya ratarata aktivitas volume perdagangan saham menjelang pengumuman peristiwa pemilihan Presiden Amerika Serikat yang bearti memberi kabar baik (good news) namun sesudah pengumuman Donald Trump pasar bereaksi yang ditunjukkan dengan penurunan rata-rata aktivitas volume perdagangan saham atau jumlah lembar saham dan minat permintaan saham dikarenakan informasi pemilihan tersebut memberi kabar buruk (bad news) sebab pengumuman hasil pemilihan Presiden Amerika Serikat 2016 Donald Trump tidak terlepas dari banyaknya media massa yang mengikut peristiwa pemilihan tersebut, dan menginformasikannya melalui media cetak maupun media elektronik karena Amerika Serikat sebagai negara adidaya dan kebijakannya dapat mempengaruhi negara-negara lain. Pemilihan Presiden Amerika Serikat 2016 selalu menjadi 
topik yang diperbincangkan mengingat adanya kebijakan-kebijakan dari salah satu kandidat yaitu Donald Trump yang inward looking tanpa terlalu memperdulikan kepentingan ekonomi global untuk melindungi perekonomian Amerika Serikat yang bersebrangan dengan kebijakan yang dikeluarkan oleh lawannya Hillary Clinton yang juga memberi indikasi bahwa investor menghindari situasi yang tidak menentu pasca terpilihhya Donald Trump sebagai Presiden Amerika Serikat.

Hasil pengujian ini konsisten dengan hasil penelitian yang dilakukan oleh Wulandari, et al, (2017); Ningsih, et al, (2014); dan Sadikin (2011). Hasil penelitian tersebut menunjukkan terdapat perbedaan rata-rata aktivitas volume perdagangan saham yang signifikan sebelum dan sesudah peristiwa.

\section{Pengaruh Pengumuman Hasil Pemilihan Presiden Amerika Serikat 2016 Donald Trump Terhadap Aktivitas Frekuensi Perdagangan Saham}

Berdasarkan uji Berdasarkan hasil pengujian frekuensi perdagangan saham dengan uji wilcoxon signed rank test, maka diperoleh nilai (Asymp.Sig) $<(0,007$ $<0,05)$. Nilai ini jelas lebih kecil dari 0,05 yang berarti mengindikasikan bahwa terdapat perbedaan aktivitas frekuensi perdagangan saham indeks LQ45 sebelum dan sesudah pengumuman hasil pemilihan Presiden Amerika Serikat 2016 Donald Trump.

Kesimpulan diambil dengan mempertimbangkan kajian teori dan emperis. Secara teoritis aktivitas frekuensi perdagangan saham adalah jumlah terjadinya transaksi perdagangan yang bersangkutan pada waktu tertentu (Taslim, 2015). Dengan melihat berapa kali atau frekuensi yang diperdagangkan, dapat dilihat bahwa saham tersebut diminati tidak oleh investor. Peristiwa pengumuman hasil pemilihan Presiden Amerika Serikat 2016 Donald Trump menyebabkan terjadinya perbedaan aktivitas frekuensi perdagangan saham yang mengindikasikan bahwa informasi pengumuman terpilihnya Donald Trump mengandung informasi dengan memberikan sinyal tentang adanya informasi buruk serta berdampak terjadinya penurunan jumlah terjadinya transaksi jual beli perdagangan dan menurunkan jumlah frekuensi transaski perdagangan dan mempengaruhi pergerakan harga saham. Sehingga mengakibatkan secara statistik terdapat perbedaan rata-rata aktivitas frekuensi perdagangan saham sebelum dan sesudah pengumuman hasil pemilihan Presiden Amerika Serikat 2016 Donald Trump. Hal ini dapat dilihat dari rata-rata aktivitas frekuensi perdagangan saham sebelum, saat, dan sesudah pengumuman hasil pemilihan Presiden Amerika Serikat 2016 Donald Trump dimana sebelum peristiwa pengumuman tersebut rata-rata aktivitas frekuensi perdagangan saham meningkat tetapi menjelang pengumuman terjadi penurunan rata-rata aktivitas frekuensi perdagangan saham yang mengindikasi informasi pemilihan tersebut sebagai kabar buruk (bad news) begitupun sesudah pengumuman terpilihnya Donald trump terjadi penurunan ratarata aktivitas frekuensi perdagangan saham yang juga memberikan kabar buruk (bad news) disebabkan oleh dalam kampanye serta kebijakan-kebijakannya Donald Trump melontarkan gagasan yang kontroversial seperti proteksionisme terhadap perdagangan dalam negerinya. Sehingga dana investor asing di pasar saham dalam negeri terus mengalami penarikan menuju pasar 
saham Amerika Serikat akibat aksi proteksionesme tersebut juga yang membuat perekonomian negara berkembang goyah terutama yang mempunyai porsi ekspor besar ke Amerika Serikat dibandingkan ekspor ke negara lain termasuk Indonesia. Padahal ekspor Indonesia merupakan komoditas mentah yang sangat rentan terhadap fluktuasi harga. Akibat kondisi tak menentu investor menunggu dan melihat dan mengatur strategi baru (rethinking new strategy) dan minat transaksi jual beli saham atau jumlah frekuensi perdagangan.

\section{PENUTUP}

\section{Kesimpulan}

Berdasarkan hasil penelitian dan pembahasan diatas, maka kesimpulan dalam penelitian ini adalah:

1. Berdasarkan hasil one-sample t-test, maka dapat disimpulkan bahwa pasar modal di Indonesia termasuk pasar yang efisien dalam bentuk setengah kuat (semistrong form). Hal ini dikarenakan pasar bereaksi dengan cepat dan tidak berkepanjangan serta menunjukkan bahwa informasi yang terkandung dalam pengumuman hasil pemilihan Presiden Amerika Serikat 2016 Donald Trump sudah bocor ke publik.

2. Berdasarkan hasil paired sample ttest, maka dapat disimpulkan bahwa secara statistik terdapat perbedaan rata-rata dengan penurunan abnormal return sebelum dan sesudah pengumuman hasil pemilihan umum Presiden Amerika Serikat 2016 Donald Trump disebabkan oleh para investor beramai-ramai melakukan profit tracking (ambil untung) dan beberapa investor beralasan meng- hindari situasi yang tidak menentu akibat kebijakan proteksionisme Donald Trump juga adanya investor asing Amerika Serikat yang menarik dananya setelah terpilihnya Donald Trump untuk berinvestasi dinegaranya.

3. Berdasarkan hasil wilcoxon signed rank test, maka dapat disimpulkan bahwa secara statistik terdapat perbedaan rata-rata dengan penurunan aktivitas volume perdagangan saham sebelum dan sesudah pengumuman hasil pemilihan Presiden Amerika Serikat 2016 Donald Trump yang tidak terlepas media masa yang mengikuti peristiwa dan kebijakankebijakan yang dikeluarkan sehingga mempengaruhi aktivitas volume perdagangan saham atau jumlah lembar saham yang diperdagangkan.

4. Berdasarkan hasil wilcoxon signed rank test, maka dapat disimpulkan bahwa secara statistik terdapat perbedaan rata-rata dengan penurunan aktivitas frekuensi perdagangan saham sebelum dan sesudah pengumuman hasil pemilihan Presiden Amerika Serikat 2016 Donald Trump dikarenakan kondisi tak tak menentu dari peristiwa pengumuman Presiden Amerika Serikat sehingga investor menunggu dan melihat dan mengatur strategi baru (rethinking new strategy) dan minat transaksi jual beli saham atau jumlah frekuensi perdagangan.

\section{Saran}

Berdasarkan hasil penelitian dan kesimpulan diatas, maka saran dalam penelitian ini adalah:

1. Bagi investor sehubungan dengan keputusan dalam menanamkan modal harus lebih berhati-hati dan mempertimbangkan kandungan 
informasi yang kemungkinan berpengaruh terhadap kinerja portofolio investasinya, agar pasar tetap berjalan secara efisien.

2. Bagi perusahan diharapkan mampu menentukan kebijakan yang tepat dalam menghadapi marketshock, dengan harapan kebijakan tersebut mampu menjaga likuiditasnya di pasar.

3. Bagi pemerintah dan lembaga terkait diharapkan mampu memberikan insentif terkait adanya marketshock, sehingga tidak ada kepanikan yang berlebihan yang dikhawatirkan dapat menurunkan kinerja pasar modal, pemerintah tersebut harus melakukan koordi-nasi dengan lembaga terkait untuk mencegah anomali yang mungkin terjadi.

4. Bagi penelitian selanjutnya diharapkan dapat menguji reaksi pasar terhadap suatu informasi dengan memperluas sampel penelitian tidak hanya menggunakan indeks LQ45 saja dan menggunakan variabel lain seperti variabel bid-ask spread. Penelitian selanjutnya dapat digunakan metode lain untuk menghitung abnormal return seperti mean adjusted model dan market adjusted model, sehingga dapat diketahui perbedannya.

\section{DAFTAR PUSTAKA}

\section{BUKU}

Jogiyanto. 2016. Teori Portofollio dan Analisis Investasi. Edisi Kesepuluh. Yogyakarta: BPFE-Yogyakarta.

\footnotetext{
Sugiyono. 2016. Metode Penelitian Kuantitatif, Kualitatif, dan R\&D. Alfabeta. Bandung.
}

Tandelilin. 2010. Portofolio dan Inevestasi. Edisi Pertama. Yogyakarta: Penerbit Kanisiu (Anggota IKAPI).

Wardhani. 2013. Manajemen Keuangan Perusahaan. Edisi tiga. Jilid satu. Malang: Bayu Media Publishing.

\section{JURNAL}

Darwis. 2013. Pengaruh Volume Perdagangan Terhadap Return Saham LQ-45 Selama Bulan Ramadhan di BEI. STIE MDP.

Devi. 2016. Pengaruh Reverse Stock Split Terhadap Volume Perdagangan, Likuiditas, dan Risiko Saham (Studi Pada Perusahaan Yang Terdaftar Di Bursa Efek Indonesia Tahun 2008 2012). Universitas Pasundan.

Jagrataraning. 2016. Pengaruh Pengumuman Dividen Saham Terhadap Abnormal Return dan Trading Volume Activity Saham di Bursa Efek Indonesia. Yogyakarta. Universitas Negeri Yogyakarta.

Inda Kristiana dan Sri Suranta. 2005. Reaksi Pasar Modal Terhadap Peristiwa Pemilu Legislatif dan Peristiwa Pemilu Presiden dan Wakil Presiden Tahun 2004 (Event Study Peristiwa Pemilu 5 April 2004 dan Pemilu 20 September 2004). Jurnal Akuntansi dan Bisnis. Vol. 5 No. 2. Agustus 2005. Hal 122136.

Kurniawan. 2014. Analisis Pengaruh Volume Perdagangan Saham, Frekuensi Perdagangan Saham, Dan Hari Perdagangan Saham Terhadap Return Saham (Studi Kasus Pada Perusahaan Farmasi yang Terdaftar di BEI Periode 2011-2013). Semarang. Universitas Negeri Semarang.

Lestari. 2014. Analisis Perbandingan Abnormal Return dan Volume Perdagangan Saham Sebelum dan Setelah Merger dan Akuisisi (Studi Kasus: Perbankan yang Terdaftar di BEI, Periode 20082013). Semarang. Universitas Negeri Semarang. 
Nurlita, dkk. 2017. Analisis Perbedaan Abnormal Return dan Trading Volume Activity (TVA) Sebelum dan Sesudah Internet Financial Reporting (IFR) (Event Study Pada Saham LQ45 Yang Terdaftar Di Bursa Efek Indonesia Periode Agustus 2015 - Juli 2016). Universitas Pendidikan Ganesha.

Pratama, Bhakti. 2015. Reaksi Pasar Modal Indonesia Terhadap Peristiwa Politik (Event Study pada peristiwa pelantikan Joko Widodo sebagi Presiden Republik Indonesia ke-7). Singaraja. Universitas Pendidikan Ganesha.

Rivaldi. 2016. Perlindungan Hukum Terhadap Investor Dalam Transaksi Jual Beli Saham Secara Online (Online Trading). Padang. Universitas Andalas.

Sauqi. 2015. Pengaruh Pengumuman Hasil Pemilihan Umum Presiden 2014 Terhadap Abnormal Return dan Aktivitas Volume Perdagangan Saham. Pekalongan. STIE Muhammadiyah.

Sihotang, Maria. 2015. Reaksi Pasar Modal Terhadap Pemilihan Umum Presiden Tanggal 9 Juli 2014 Di Indonesia. Manado. Universitas Sam Ratulangi.

Silviyani, dkk. 2014. Pengaruh Likuiditas Perdagangan Saham dan Kapitalisasi Pasar Terhadap ReturnSaham Perusahaan Yang Berada Pada Indeks Lq45 Di Bursa Efek Indonesia Periode Tahun 2009-2013 (Studi Empiris Pada Perusahaan Lq45 Di Bursa Efek Indonesia). e-Journal S1 Ak Universitas Pendidikan GaneshaJurusan Akuntansi SI (Volume: 2 No. 1 Tahun 2014).

Suparsa, I made Joni. 2014. Perbedaan Abnormal Return dan Trading Volume Activity Atas Pengumuman Kenaikan Harga BBM Pada Saham yang Tergolong LQ-45. E-Jurnal Universitas Udayana, 7 (2): h: 382-389.

Tarigan, Dastanta. 2015. Pengaruh Indeks Harga Saham Global Terhadap Indeks Harga Saham Gabungan (IHSG) Studi
Pada Bursa Efek Indonesia (BEI) Periode 2011-2014. Malang. Universitas Brawijaya.

Taslim. 2015. Analisis Pengaruh Volume Perdagangan Saham, Frekuensi Perdagangan Saham, Dan Hari Perdagangan Saham Terhadap Return Saham (Studi Kasus Pada Perusahaan Farmasi yang Terdaftar di BEI Periode 2011-2013). Semarang. Universitas Negeri Semarang.

Wibowo. 2017. Reaksi Investor Pasar Modal Indonesia Terhadap Paket Kebijakan Ekonomi Tahap I Jokowi-JK (Studi Peristiwa Pada Saham LQ45 Periode Agustus 2015-Pebruari 2016). Semarang. UNTAG Semarang.

Yusuf, Dewi. 2009. Analisis Reaksi Investor Terhadap Pengumuman Right Issue Di Bursa Efek Jakarta. Wacana. Vol 12 No 4 Oktober.

Yuwono. 2013. Reaksi Pasar Modal Di Bursa Efek Indonesia Terhadap Pengumuman Peristiwa Bencana Banjir Yang Melanda Daerah Khusus Ibu Kota Jakarta Tahun 2013. Yogyakarta. Universitas Negeri Yogyakarta.

\section{WEB}

http://bisniskeuangan.kompas.com/read/201 6/11/12/060120726/efek.trump.men g uji.perekonomian.indonesia, Diakses pada tanggal 20 februari 2017, Jam 18;03 WIB.

http://www.bkpm.go.id/, Diakses pada tanggal 23 Februari 2017, Jam 13.05 WIB.

http://www.idx.co.id, Diakses pada tanggal 28 Maret 2017, Jam 10.33 WIB.

http://www.iaiglobal.or.id, diakses pada tanggal 17 Juli 2017

http://www.sahamok.com, Diakses pada tanggal 24 Maret 2017, Jam 08.00 WIB

http://www.kompasiana.com/siroj_boot_bois 87/dampak-terpilinnya-donaldtrump-terhadap-ekonomi-diindonesia_584ea82a4523bdde166ea 
$5 \mathrm{~cd}$, Diakses pada tanggal 20

Februari 2017, Jam 7:32 WIB.

http://www.sahamok.com, Diakses pada

tanggal 28 Maret 2017, Jam 11.03

WIB. 